\title{
A new record of Fissidens protonemaecola Sakurai (Fissidentaceae, Bryophyta) in Korea
}

\author{
Woochan KWON, Yongsung KIM and Jongsun PARK* \\ InfoBoss Co., Ltd. and InfoBoss Research Center, Seoul 06088, Korea \\ (Received 11 June 2019; Revised 15 July 2019; Accepted 11 September 2019)
}

\begin{abstract}
An unrecorded Fissidens species, Fissidens protonemaecola Sakurai (Fissidentaceae, Bryophyta), was newly discovered in Korea during an investigation bryophyte flora. In this study, we examined the morphology of $F$. protonemaecola in Korea. This species was found in soil along a train through a shaded backslope of Mt. Bukbyeongsan (elev. $80 \mathrm{~m}$ ) on Geojedo Island and on Mt. Gogeunsan (Oreum; elev. $280 \mathrm{~m}$ ) on Jejudo Island, Korea. This species has dwarfish bud-like shoots scattered on persistent protonemata. An important feature of the protonemata is a diagnostic character of F. protonemaecola that clearly distinguishes it from other Fissidens species. Its Korean name is given as "Cho-rok-sil-bong-hwang-i-kki," inferred from the characteristic protonemata of the species.
\end{abstract}

Keywords: Bryophytes, unrecorded species, Fissidens, Fissidens protonemaecola

Genus Fissidens Hedw. (Fissidentaceae: Bryophyta) is one of highly diversified genera in mosses, consisting of approximately 450 species worldwide (Crosby et al., 2000). Fissidens is the only genus that consists family Fissidentaceae (Pursell and Bruggeman-Nannenga, 2004), characterized by a sheathing part in each leaf called vaginant lamina. Japan and China nearby Korea have well-investigated moss florae including a number of Fissidens species in each country. In China, 49 species and 9 varieties of Fissidens taxa were recorded in 2001 (Li et al., 2001). Japan also recorded similar number of Fissidens taxa, 46 species and 5 varieties in 2002, but the number of taxa increased to 94 species and 5 varieties by 2017 (Suzuki and Iwatsuki, 2012; Suzuki, 2015, 2017). In contrast, 16 taxa in genus Fissidens were described in Korea until 2007 (Park and Choi, 2007) and consequence researches presented newly discovered Fissidens species (Yoon and Sun, 2010; Yoon et al., 2015a, 2015b), resulting 23 taxa (19 species and 4 varieties) in Korea. Most of these Fissidens are also identified in Japan but three out of 23 taxa are not in Japan: (1) Fissidens involutus var. jejuensis Y. J. Yoon, B. C. Tan \& B. Y. Sun which is a new variety reported from Jejudo Island (Yoon et al., 2015a), (2) Fissidens borealis C. Gao which is distributed in North Korea and China, and (3) an unresolved species, Fissidens pseudolateralis Cardot, which was firstly reported at Hallasan Mountain in Jejudo Island in 1908 and lastly recorded in the 1960s (Hong and Ando, 1962; Kim, 1968). Because the two taxa, $F$. involutus var. jejuensis and $F$. pseudolateralis, have the same Korean name, "Tam-ra-bonghwang-i-kki," more investigations of these taxa should be conducted. With active researches of Fissidens in Japan and a relatively small number of taxa in Korea, it is suspected that there may be more unrecorded Fissidens species in Korea. Here, we discovered an unrecorded species: Fissidens protonemaecola Sakurai from two islands, Geojedo Island and Jejudo Island in Korea (Fig. 1), during investigation of bryophyte flora of Korea. In addition, we examined morphological characteristics of $F$. protonemaecola to identify this species.

\section{Taxonomic Treatment}

Fissidens protonemaecola Sakurai, Bot. Mag. (Tokyo) 47: 741, 1933. Fig. 2

Fissidens gemmaceus G. Herzog \& P. de la Varde, J. Hattori Bot. Lab. 14: 55, 1955.

Korean name: Cho-rok-sil-bong-hwang-i-kki (초록실봉황 이끼).

\footnotetext{
*Author for correspondence: starflr@infoboss.co.kr
} 


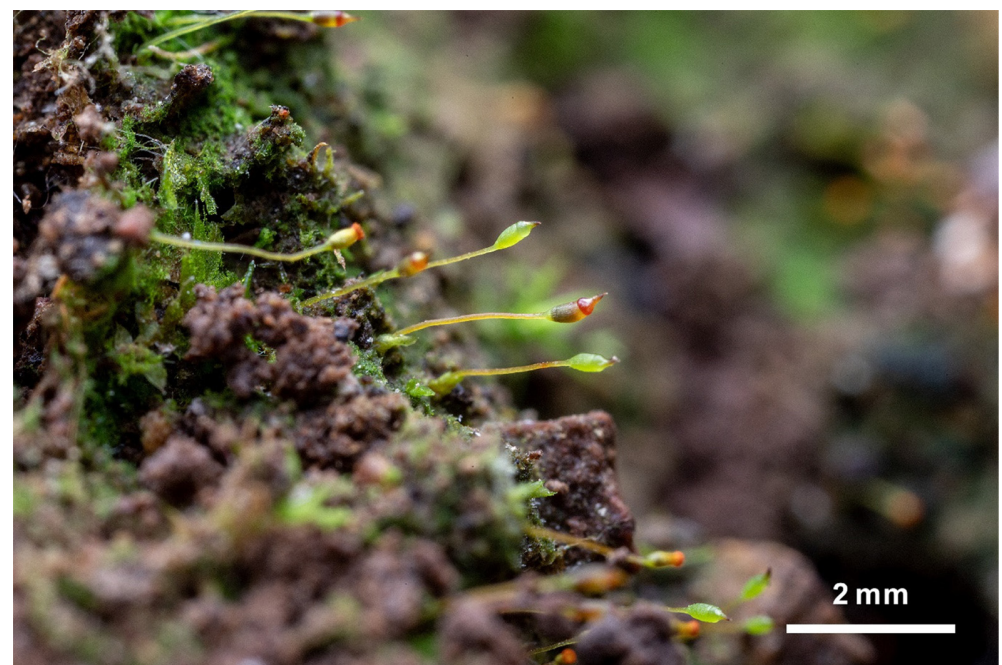

Fig. 1. A wild population of Fissidens protonemaecola in Bukbyeongsan Mountain, Geojedo Island, Korea.

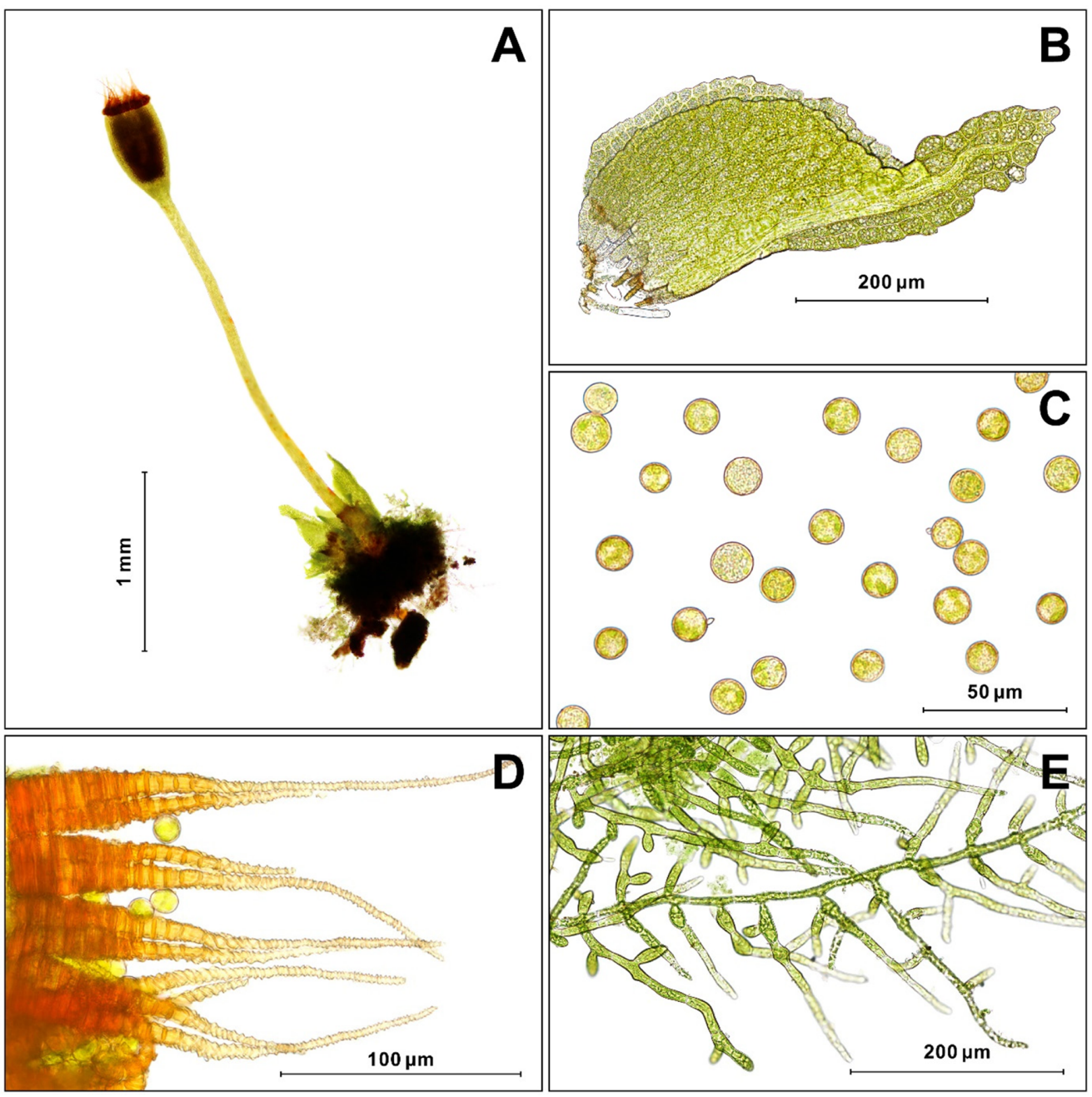

Fig. 2. Fissidens protonemaecola Sakurai. A. Female plant with sporophyte and male plant with antheridia $(\times 22)$. B. Leaf $(\times 117)$. C. Spores $(\times 350)$. D. Peristome teeth $(\times 292)$. E. Protonemata $(\times 130)$. 
Plants minute, protonemata persistent. Shoots $0.55-0.80 \times$ $0.20-0.35 \mathrm{~mm}$; stem very short; without central strand. Leaves in 1-3 pairs, $0.20-0.65 \mathrm{~mm} \times 0.10-0.20 \mathrm{~mm}$; lower leaves reduced, scale-like; upper leaves much larger, ovate-lanceolate, acute at apex; costa weak, ending a few cells below leaf apex; vaginant laminae large, rounded, extending to $2 / 3$ of leaf apex; apical and dorsal laminae small, narrowly oblong; margins crenulate to undulate; cells of vaginant laminae oblonghexagonal, $25-40 \mu \mathrm{m}$, smaller toward the leaf margin, rhomboidal, $12-25 \times 12-16 \mu \mathrm{m}$, somewhat elongate near costa, to $70 \mu \mathrm{m}$ long; cells of dorsal and apical laminae obscure, rhomboid-hexagonal, 20-30 × 14-20 $\mu \mathrm{m}$. Rhizautoicous. Seta terminal, 1.5-2.0 mm long, 0.55-0.65 mm thick. Capsule erect, oblong, ovoid when dry, $0.30-0.45 \times 0.15-0.20 \mathrm{~mm}$. Operculum rostrate, $0.28-0.35 \mathrm{~mm}$ long. Peristome teeth 16 , divided to half their length, $0.16-0.24 \mathrm{~mm}$ long, ca. $35 \mu \mathrm{m}$ wide at base. Spores 10-13 $\mu \mathrm{m}$, spherical, smooth. Calyptra mitrate, to $0.35 \mathrm{~mm}$ long. Perigonium $0.30-0.35 \mathrm{~mm}$ long.

Habitats: the plants were found on the soil in shaded backslope of the trails of Bukbyeongsan Mountain (elev. 80 $\mathrm{m}$ ) in Geojedo Island and Gogeunsan Mountain (Oreum; elev. $280 \mathrm{~m}$ ) in Jejudo Island, Korea.

Distribution: China, Japan, Taiwan (Noguchi, 1987; Li et al., 2001); new to Korea.

Specimens examined: KOREA. Gyeongsangnam-do: Geoje-si, Dongbu-myeon, Bukbyeongsan Mountain, 8 Feb 2019, W. Kwon KBDS01313 (IN). Jeju-do: Seogwipo-si, Seoho-dong, Gogeunsan Mountain (Oreum), 22 Feb 2019, $W$. Kwon KBDS01488 (IN).

This species has dwarfish bud-like shoots scattered on persistent protonemata. The feature of protonemata is a diagnostic character of $F$. protonemaecola that clearly distinguishes from other Fissidens species. Two morphologically most related species, Fissidens closteri ssp. kiusiuensis (Sakurai) Z. Iwats., and Fissidens macaoensis L. Zhang, also have extremely small size, but their protonemata are not persistent (Zhang and Hong, 2011). Among the Korean species of Fissidens, Fissidens hyalinus Wilson \& Hook. is the closest allied species to F. protonemaecola in phylogenetic tree and these two species belong to subgen. Fissidens sect. Polypodiopsis (Suzuki et al., 2018). The genus Fissidens is classified into three subgenera, Fissidens, Neoamblyothallia, and Pachyfissidens (Suzuki et al., 2018). They are characterized by unique morphology of peristome teeth (Suzuki et al., 2018). Members of sect. Polypodiopsis, belonging to subgen. Fissidens, share Thorsbornei-type costae in cross sections and large parenchymatous cells of laminae (Suzuki et al., 2018); however, the two species of sect. Polypodiopsis, $F$. protonemaecola, and $F$. hyalinus are easily distinguishable by plants size and existence of costa.

New Korean name is given as "Cho-rok-sil-bong-hwang-ikki," is named for the characteristic protonema, which is a diagnostic character of the species.

ORCID: Woochan KWON https://orcid.org/0000-0001-86658097; Yongsung KIM https://orcid.org/0000-0002-5349-9226; Jongsun PARK https://orcid.org/0000-0003-0786-4701.

\section{Acknowledgments}

This work was supported by both InfoBoss Research Grant [IBP-0002] and 'The Consortium of Korea Biodiversity and Sustainable Use' at the Ministry of Environment, Korea.

\section{Conflict of Interest}

The authors declare that there are no conflicts of interest.

\section{Literature Cited}

Crosby, M. R., R. E. Magill, B. Allen and S. He. 2000. A Checklist of the Mosses. Missouri Botanical Garden Press, St. Louis, MO, $320 \mathrm{pp}$.

Hong, W. S. and H. Ando. 1962. The moss flora of Mt. Hanla, Quelpart Island (1). Hikobia 3: 86-95.

Kim, I. H. 1968. Bryophytes. In Halasan and Hongdo. Ministry of Culture and Public Information, Korea (ed.), Dongboo, Seoul. Pp. 153-159. (in Korean)

Li, X. J., M. R. Crosby, S. He and Z. Iwatsuki. 2001. Moss Flora of China, Vol. 2. Fissidentaceae - Ptychomitriaceae. Missouri Botanical Garden Press, Beijing, 283 pp.

Noguchi, A. 1987. Illustrated Moss Flora of Japan I. Daigaku Printing Co., Ltd., Hirosima. Pp. 62-64.

Park, K. W. and K. Choi. 2007. New List of Bryophytes of Korea. Korea National Arboretum, Pocheon, 150 pp. (in Korean)

Pursell, R. A. and M. A. Bruggeman-Nannenga. 2004. A revision of the infrageneric taxa of Fissidens. Bryologist 107: 1-20.

Suzuki, T. 2015. Notes on Fissidens (Fissidentaceae, Bryopsida) in Japan. Hattoria 6: 1-25.

Suzuki, T. 2017. Many interesting mosses newly found in Japan. Hattoria 8: 1-88.

Suzuki, T., Y. Inoue and H. Tsubota. 2018. Molecular phylogeny of the genus Fissidens (Fissidentaceae, Bryophyta) and a refinement of the infrageneric classification. Molecular Phylogenetics and Evolution 127: 190-202.

Suzuki, T. and Z. Iwatsuki. 2012. Fissidens (Fissidentaceae, 
Bryopsida) species newly found in Japan. Hattoria 3: 1-48.

Yoon, Y. J. and B.-Y. Sun. 2010. Four unrecorded moss species from the Korean flora. Korean Journal of Plant Taxonomy 40: 186-191.

Yoon, Y.-J., B. C. Tan, C.-H. Kim and B.-Y. Sun. 2015a. Ten new records of South Korean mosses. Arctoa 24: 37-42.
Yoon, Y.-J., B. C. Tan and B.-Y. Sun. 2015b. Seven new records of overlooked South Korean moss species. Hattoria 6: 57-61.

Zhang, L. and P. I. Hong. 2011. A new species of Fissidens with remarkable rhizoidal tubers and gemmae from Macao, China. Journal of Bryology 33: 50-53. 